\title{
Job Satisfaction of Iowa Public School Principals
}

\author{
Boris Sodoma \\ David Else \\ University of Northern Iowa
}

\begin{abstract}
The purpose of this study was to examine the job satisfaction of Iowa public school principals and contrast the job satisfaction to the perceptions six years previously. The population for the 1999 and 2005 study was a sample of principals from Iowa K-12 schools. The study revealed significant differences in overall job satisfaction, in gender of the principals, years served as a principal, and type of schools in both studies. No significant differences were found for years served in present position. The results indicated that principals were overall more satisfied in the 2005 than they were in 1999. The findings confirmed that principals spent more time on the management of their schools than on leadership tasks. Principals were more satisfied with hygiene factors than with motivators in both studies.
\end{abstract}

In recent decades, job satisfaction has been the theme of numerous studies in both public and private organizations. Little attention has been given to job satisfaction among public school principals serving at elementary and secondary levels (Mack, 2000; Sablatura, 2002). The review of the literature showed that there is not a systematic research effort to study job satisfaction of public school principals in the United States. More of the current studies are doctoral dissertations. Without knowing the perceptions of principals about satisfaction and dissatisfaction with their work, school boards and legislators will not be able to help principals get rid of the barriers that inhibit their work and their effectiveness.

On a daily basis a wide variety of demands are being placed on principals. The legislature and taxpayers demand more services, industry expects competent workers, parents insist that social issues ought to be addressed, and the public wants achievement scores to improve. A sharp increase in responsibilities in recent years has made the job of principals more stressful (National Association of Elementary School Principals, 2003). Demands placed on principals have changed, but the profession has not changed to meet these demands, and tension is starting to show. Principals today too often are not ready to meet the demands of their position (Institute for Educational Leadership, 2000). Research findings indicate that one-third of school principals were not prepared for what the school expected of them (Schmidt, Weaver, \& Aldredge, 2001). A new educator coming to the principalship can be confused about what is expected, what is needed, and what should be done. A sharp increase in responsibilities in recent years has made the job of a principal stressful and has discouraged teachers from taking positions in administration (NAESP, 2003). Principals are now being held more accountable for the performance of students, while at the same time they are required to adhere to a growing number of government regulations. In addition, overcrowded classrooms, safety issues, and teacher shortages are all creating additional pressures on principals (Institute for Educational Leadership, 2000).

Demands of the job and the time it consumes are two barriers for entering the principalship (Else \& Sodoma, 1999). Principals confirm this trend, especially those at the high school level and women administrators. As a result, principals are incredibly pressed for time and energy. District administrators and boards of education have not addressed the issue of job satisfaction as it relates to retaining principals and increasing the candidate pool (Educational Research Service, 2000; Blackman \& Fenwick, 2000; NAESP, 2003). The increase in pay is often not enough to entice people into the field (Blackman \& Fenwick, 2000). Unless principals are valued adequately for their rapidly expanding roles, communities will be unable to recruit and retain leaders they need (Institute for Educational Leadership, 2000). Determining the job satisfaction level of principals in Iowa provides insight into the demands of the principalship and the support that principals need in order to feel satisfaction in their jobs.

With growing emphasis on accountability, standards, and high-stakes testing, we have to wonder what impact the demands for raising student achievement and closing the achievement gap has had on principal job satisfaction. Since the initial Iowa study in 1995, minimal allowable growth in per pupil spending, state budget cuts, endless mandates, ever present litigation, declining student enrollment, and growing concerns about violence have increased the pressures on principals. Have all these challenges combined with the 
requirement of the No Child Left Behind Act (2001) affected the job satisfaction of Iowa public school principals?

Herzberg's Two-Factor Theory posits that workers are more likely to be motivated by motivators than by hygiene factors. This prediction is based on the theory that claims that motivators (achievement, recognition, work itself, responsibility, advancement, and possibility of growth) are the factors that lead to job satisfaction. Hygiene factors (company policy and administration, supervision, interpersonal relations, working conditions, and salary) contribute very little to job satisfaction. Hygiene factors do not satisfy workers, but their absence will lead to dissatisfaction (Herzberg, Mausner, \& Snyderman, 1959).

The goal of this study was not to test Herzberg's dual continuum hypothesis. The researchers hoped that final results showed whether there was a significant change from the 1999 study to the 2005 study in motivators and hygiene factors for Iowa principals' job satisfaction as defined by Herzberg's Two-Factor Theory (1959).

Based upon a review of the current literature, four major research questions were examined.

\section{Research Questions}

1. What is the overall level of job satisfaction of Iowa public school principals? (a) What is the overall level of job satisfaction according to gender, years served as a principal, years served in present school, and type of school? (b) What is the level of job satisfaction for each of the 20 identified factors for Iowa public school principals? (c) What is the satisfaction level for each of the 20 identified factors according to gender, years served as a principal, years served in present school, and type of school?

2. Is there a significant difference in overall principal job satisfaction in 2005 when contrasted with job satisfaction in 1999? Is there a difference in: (a) overall job satisfaction according to gender, years served as a principal, years served in present school, and type of school? (b) each of the 20 identified factors of Iowa public school principals? (c) each of the 20 factors according to gender, years served as a principal, years served in present school, and type of school?

3. Is there a significant relationship between overall job satisfaction of Iowa school principals and time spent on educational leadership activities and management tasks?

4. Has there been a significant change from the 1999 study to the 2005 study in motivators and hygiene factors for Iowa principal job satisfaction as defined by Herzberg's Two-Factor Theory?

\section{Method}

Herzberg's original data were obtained through qualitative methods. While qualitative methodology (a) includes focus groups, unstructured or semi structured response options and in-depth interviews; (b) is text based; (c) depends on the skill of the researcher; (d) describes a problem from the point of view of those experiencing it; and (e) is less generalizable, quantitative methodology (a) uses surveys, (b) applies statistical tests for analysis, (c) is number based, (d) uses fixed response options, (e) is more objective, (f) can be valid and reliable, depending on the instrument used, (g) is heavier on the planning and lighter on the analysis and (h) is more generalizable.

The survey method of research was selected because it provides a systematic data collection tool to reach many people (Salant \& Dillman, 1994). Using quantitative methodology to collect data, the findings of this study provide a more comprehensive view of Herzberg's theory. Furthermore, the methodology used to collect and analyze data within Iowa can serve as a model for conducting similar research on school principals in other states of the United States.

\section{Participants}

In both studies, the population for the study was Iowa public elementary, middle, and high school principals. While in the 1999 study all Iowa public school principals were contacted, a sample of 300 principals stratified by elementary, middle, and high school was proportionally drawn against the population of principals. Participants received questionnaires regarding selecting demographic characteristics and statements related to job satisfaction. The respondents were asked to indicate the level of satisfaction or dissatisfaction by checking an item corresponding to one of the five categories: 1 = Very satisfied, $2=$ Moderately satisfied, $3=$ Neutral, $4=$ Moderately dissatisfied, $5=$ Very dissatisfied.

\section{Preparing to Teach in Rural Schools}

Rural educators have long been asking for special preparation for new teachers to teach in rural schools. Barker and Beckner (1985) conducted a survey of 473 fouryear public colleges and universities with teacher training programs about their program's emphases. The five areas relevant to rural schools they identified are shown in Table 1 in the first column. For this study, the second and fifth areas have been combined under the heading Courses Focused on Rural Conditions. The areas of Being Prepared in Two or More Content Areas and Offering Student Teaching in Rural Schools as identified by Barker and Bekner (1985) have also been included.

\section{Instrument}

The questionnaire for the study was developed specifically after consulting surveys from several disciplines including education and management. The researchers of the 1999 study decided to develop their own instruments to include a separate set of job categories related to the 
everyday work activities under investigation for the study of Iowa public school principals. The questionnaire was piloted to assess how much time the respondents needed to complete the questionnaire, in addition to clarity and the ease of responding to the questionnaire. The questionnaire was modified in form and content after recommendations from a group of Iowa public school principals and University of Northern Iowa professors to assure the validity of the instrument. Cronbach's Alpha reliability coefficient of internal consistency for all job satisfaction questions was .89. A widely accepted minimum standard for internal consistency is .70. The overall alpha coefficient was comparable with other instruments used in educational settings. The questions measuring the job satisfaction were:

1. The sense of accomplishment you receive from your work.

2. Professional growth opportunities for you.

3. The adequacy of administrative support provided for you.

4. The adequacy of support services provided for you.

5. Community demands placed on you as a principal.

6. Extracurricular demands placed on you as a principal.

7. Time available for activities that put balance in your life.

8. Relations with the administrative team/cabinet.

9. Relations with the board of education.

10. Relations with the parents of your school.

11. Relations with the teachers of your school.

12. The consistency of the board in making decisions in the best interest of students.

13. How well the board of education acknowledges your accomplishments.

14. Your annual salary.

15. The community's image of school administrators.

16. Time spent on management tasks, i.e. budgeting, staffing, planning.

17. Time spent on leadership tasks, i.e., facilitating development of shared vision for the school, etc.

18. The quality of your relationship with the superintendent.

19. The process the superintendent uses to evaluate you.

20. All things considered, indicate your overall level of job satisfaction.

\section{Collection of Data}

In March 1999, the questionnaires were mailed to all Iowa public elementary, middle/junior high, and high school principals. The same process was utilized in the 2005 study. All data collected were studied as group data. In order to avoid non-response error, late respondents were compared with respondents in order to obtain information about the differences of the group. No significant differences were found between these two groups of principals. Respondents marked their responses directly on the questionnaire.

\section{Data Analysis}

Overall job satisfaction, satisfaction related to the job itself, and job context were described by descriptive statistics including numbers and percentages, means, and standard deviations. The analysis of the demographic data to overall job satisfaction was provided by $t$-tests, analysis of variance (ANOVA), and Scheffé post hoc tests. Correlations were calculated to describe the relationship or strength of association among overall job satisfaction, educational leadership activities, and management tasks.

\section{Results}

The findings in 1999 showed that in overall job satisfaction, $76 \%$ of respondents fell within the moderately satisfied range on the scale $(M=2.04, S D=0.80)$. The results showed that the calculated mean $(M)$ and standard deviation $(S D)$ in overall job satisfaction for respondents in the 2005 study was $(M=1.95)$ with $(S D)=0.74)$. The mean for the respondents fell within the very satisfied range on the scale.

In the 2005 study, $64.3 \%$ of Iowa public school principals responded. There were no significant changes in demographics from the 1999 study. The majority of the respondents in 2005 study were male (65.8\%) while 34.2\% were female. Nearly all principals were white (98.4), except other racial/ethnic groups representing African-American (1.1\%), Hispanic (0.5\%). Within age categories, $71 \%$ of the principals were 41-60 years old, while 25.9\% were below 40 ; only $2.6 \%$ were above 60 years of age. Forty-four percent of the respondents were principals of schools with enrollments between 300 and 599 students. Thirty-five percent served in schools of 600 pupils or more, while 24.4\% were at schools with less than 300 students enrolled. More than half of the respondents (51.3\%) had served as principal for 1-10 years and 31.6\% had served for $11-20$ years. Thirteen and half percent had served for 21-30 years and only $3.6 \%$ of the respondents had served more than 30 years.

More than half of the principals (51.3\%) had served at their present school for 1-5 years, 25.9\% had served 6-10 years and $22.8 \%$ had served more than 10 years. Just under half of the respondents $(45.6 \%)$, were employed in elementary schools, another $25.4 \%$ worked in middle schools and $29 \%$ were principals in high schools. Despite the increasing responsibilities of the job, the results showed that principals in 2005 were overall very satisfied with their jobs compared to the 1999 principals who were moderately satisfied (using the scale 1 = Very satisfied, 2 = Moderately satisfied, 3 = Neutral, 4 = Moderately dissatisfied, 5 = Very dissatisfied). 
Principals were very satisfied in both studies with the relationships with teachers, parents, administrative team/cabinet; board of education; with the quality of relationship with the superintendent; and with sense of accomplishments. They were less satisfied with time community demands placed on them, salary and the community's image of school administrators. The time available for activities that put balance in the life of principals, extracurricular demands, and time spent on leadership and management tasks were factors that were rated with lower satisfaction in both studies. The findings confirmed that principals spent more time on the management of their schools than on leadership tasks. Principals were more satisfied with hygiene factors than with motivators in both studies.

The results indicate a statistically significant difference for overall job satisfaction for all respondents in the 1999 and the 2005 studies: $t(1082)=2.24, p<.03$, with means of 2.04 versus 1.90 . Statistically significant differences were found in overall job satisfaction between male and female principals $(t(1080)=2.42, p<.02)$, by years served as a principal for those having served from 1-5 years, $(t(327)=$ $2.08, p<.04)$ and from $11-15$ years $(t(203)=2.19, p<.03)$ and by middle/junior high school principals $(t(205)=2.04, p$ $<.04)$. No statistically significance was found for principals according to the years served in their present school.
Results of the analysis of the 1999 study showed a statistically significant positive moderate correlation between time spent on leadership activities and overall job satisfaction $\left(r(891)=0.32, r^{2}, p<.01\right)$ and between time on management tasks and overall job satisfaction $(r(891)=$ $\left.0.32, r^{2}, p<.01\right)$. In overall job satisfaction, $10.4 \%$ of the variance could be accounted for by satisfaction with time spent on leadership activities and management tasks. The results of the 2005 study showed a statistically significant, positive moderate correlation between time spent on leadership activities and overall job satisfaction, $(r(192)=$ $0.38, r^{2}, p<.01$ ), with $14.82 \%$ of the variance attributed to time spent on leadership activities, and between time spent on management tasks and overall job satisfaction $(r(192)=$ $0.39, r^{2}, p<.01$ ), with $14.97 \%$ of the variance accounted for by satisfaction with time spent on management tasks.

The results of independent $t$-test presented in Table 1 indicate statistically significant differences in the motivators for the 1999 and the 2005 study. Statistically significant differences in the hygiene factors reported in Table 2 were found for the 1999 and the 2005 study. Means $(M)$ for motivators in both studies presented in Table 3 were 2.63 versus 2.51 and for hygiene factors reported in Table 4 were 2.29 versus 2.18 respectively. The results showed higher means in the 2005 study for both motivators and hygiene factors.

\section{Table 1}

Significant Differences in the Motivators for the 1999 Study and the 2005 Study

\begin{tabular}{|l|l|}
\hline 1. How well the board of education acknowledges the principal's accomplishments. & $t(1082)=2.11, p<.04^{*}$ \\
\hline 2. The community's image of a school administrator. & $t(1082)=2.03, p<.04^{*}$ \\
\hline 3. The process the superintendent uses to evaluate you. & $t(1070)=3.02, p<.01^{*}$ \\
\hline
\end{tabular}

*The mean is significant at the .05 level (2-tailed). 
Table 2

Significant Differences in the Hygiene Factors for the 1999 Study and the 2005 Study

\begin{tabular}{|l|l|}
\hline 1. Time available for activities that put balance in a principal's life. & $t(1081)=2.16, p<.03^{*}$ \\
\hline 2. The consistency of the board in making decisions in the best interest of the children. & $t(1083)=2.53, p<.02^{*}$ \\
\hline 3. Your annual salary. & $t(1082)=3.63, p<.01^{* *}$ \\
\hline
\end{tabular}

*The mean is significant at the .05 level (2-tailed).

** The mean is significant at .01 level (2-tailed).

Table 3

Means for the Motivators in the 1999 and the 2005 Studies*

\begin{tabular}{|c|c|c|c|c|}
\hline Factors & 1999-2005 Study & $N$ & $M$ & $S D$ \\
\hline \multirow[t]{2}{*}{ 1. The sense of accomplishment a principal receives from the work. } & 1999 & 890 & 1.73 & .71 \\
\hline & 2005 & 193 & 1.79 & .83 \\
\hline \multirow{2}{*}{ 2. Professional growth opportunities provided for you. } & 1999 & 890 & 2.13 & .94 \\
\hline & 2005 & 193 & 2.11 & .93 \\
\hline \multirow[t]{2}{*}{ 3. Extracurricular activities placed on you as a principal. } & 1999 & 892 & 3.07 & .98 \\
\hline & 2005 & 193 & 2.90 & 1.02 \\
\hline \multirow{2}{*}{ 4. The community demands placed on you as a principal. } & 1999 & 891 & 2.63 & 1.11 \\
\hline & 2005 & 193 & 2.58 & 1.18 \\
\hline \multirow{2}{*}{ 5. How well the board of education acknowledges your accomplishment. } & 1999 & 891 & 2.72 & 1.21 \\
\hline & 2005 & 193 & 2.51 & 1.28 \\
\hline \multirow[t]{2}{*}{ 6. The community's image of the school administrators. } & 1999 & 891 & 2.65 & 1.02 \\
\hline & 2005 & 193 & 2.48 & 1.04 \\
\hline \multirow[t]{2}{*}{ 7. Time spent on management tasks. } & 1999 & 892 & 3.13 & .99 \\
\hline & 2005 & 193 & 3.05 & 1.01 \\
\hline \multirow[t]{2}{*}{ 8. Time spent on leadership activities. } & 1999 & 892 & 3.17 & 1.05 \\
\hline & 2005 & 193 & 3.05 & 1.05 \\
\hline \multirow[t]{2}{*}{ 9. The process the superintendent uses to evaluate you. } & 1999 & 879 & 2.46 & 1.18 \\
\hline & 2005 & 193 & 2.19 & 1.07 \\
\hline
\end{tabular}

\footnotetext{
*Mean for 1999 study: 2.63; Mean for 2005 study: 2.51
} 
Table 4

Mean for the Hygiene Factors in the 1999 and 2005 Studies*

\begin{tabular}{|c|c|c|c|c|}
\hline Factors & 1999-2005 Study & $N$ & $M$ & $S D$ \\
\hline \multirow[t]{2}{*}{ 1. The adequacy of administrative services provided for you. } & 1999 & 891 & 2.21 & 1.10 \\
\hline & 2005 & 193 & 2.31 & .91 \\
\hline \multirow[t]{2}{*}{ 2. The adequacy of support services provided for you. } & 1999 & 888 & 2.47 & .94 \\
\hline & 2005 & 193 & 2.45 & 1.02 \\
\hline \multirow[t]{2}{*}{ 3. Time available for activities that put balance in your life. } & 1999 & 890 & 3.68 & 1.09 \\
\hline & 2005 & 193 & 3.49 & 1.07 \\
\hline \multirow[t]{2}{*}{ 4. Relationship with the administrative team/cabinet. } & 1999 & 892 & 1.89 & 1.03 \\
\hline & 2005 & 193 & 1.81 & 1.08 \\
\hline \multirow[t]{2}{*}{ 5. Relationship with the board of education. } & 1999 & 887 & 2.11 & 1.08 \\
\hline & 2005 & 193 & 1.98 & 1.09 \\
\hline \multirow[t]{2}{*}{ 6. Relationship with the parents of the school. } & 1999 & 891 & 1.74 & .67 \\
\hline & 2005 & 193 & 1.71 & .67 \\
\hline \multirow[t]{2}{*}{ 7. Relationship with the teachers of the school. } & 1999 & 891 & 1.62 & .69 \\
\hline & 2005 & 193 & 1.57 & .72 \\
\hline \multirow{2}{*}{$\begin{array}{l}\text { 8. The consistency of the board in making decisions in the best interest of } \\
\text { children. }\end{array}$} & 1999 & 892 & 2.31 & 1.14 \\
\hline & 2005 & 193 & 2.07 & 1.13 \\
\hline \multirow[t]{2}{*}{ 9. Your annual salary. } & 1999 & 891 & 2.97 & 1.19 \\
\hline & 2005 & 193 & 2.63 & 1.10 \\
\hline \multirow[t]{2}{*}{ 10. The quality of your relationship with the superintendent. } & 1999 & 886 & 1.89 & 1.10 \\
\hline & 2005 & 193 & 1.77 & 1.05 \\
\hline
\end{tabular}

*Mean for 1999 study: 2.29; Mean for 2005 study: 2.18

\section{Discussion}

Principals in 2005 were more satisfied than they were in 1999. This is interesting because during these six years greater focus has been placed on raising student achievement and closing the achievement gap through pressures to show proficiency in the growth mandated by the No Child Left Behind Act (2001). All Iowa school districts also experienced two budget cuts and educational funding experienced minimal allowable growth. In some Iowa school districts student populations became much more culturally diverse. So why were Iowa public school principals more satisfied in 2005? One can only speculate that principals feel more responsible for student success.
Perhaps they see themselves more as educational and instructional leaders than in the past. Principals tend to have a close working relationship with teachers, parents, board of education members and other stakeholders. Perhaps the additional pressures since 1999 have improved the relationship to work together.

Principals expressed high satisfaction with the 20 factors on the Iowa satisfaction questionnaire. The results show that significantly different factors with lower satisfaction scores in both studies reached higher satisfaction means in the 2005 study. On the other hand, these results call attention to the fact that principals are still very busy and overwhelmed by school activities not only during regular work days but many times also on weekends. 


\section{Educational Leaders or Managers?}

In both studies principals continued to be less satisfied with extracurricular activities, with time for activities that put balance in the life of principals, and with time spent on management tasks than time spent on education leadership tasks. This trend contradicts the expectations of the public, who want principals to be educational leaders of their school, not just managers of school affairs (Else \& Sodoma, 1999; Rayfield \& Diamantes, 2003). In both studies, principals were spending less time on leadership activities which causes less satisfaction in their jobs. These problems result in principals leaving the principalship and teachers or other school administrators licensed for K-12 schools not wanting to enter the principalship (Behrens, 2003). Principals need support so they can spend less time on management tasks and more time on leadership activities. Schools also need to reduce demands outside of the school so principals have more time to put balance in their lives.

Principals are also less satisfied with the image they have as community school administrators. A discrepancy exists between principals and the school board's consistency in making decisions in the best interests of students and in how well the board of education acknowledges principals' accomplishments. These recognition factors point out that principals are very sensitive to their superiors' evaluation of their work. Their professional view of educational problems and expertise are confronted by the community's and board's view, and their opinions on questions of everyday school activities are sometimes exposed to the unnecessary tension between school board and principals. However, this does not seem to impact their overall satisfaction with the job.

\section{High Relationship with Parents and Teachers}

In 1999 and also in 2005, the relationships with teachers, and parents were high and principals said they are very satisfied or moderately satisfied with these relationships. Principals give high ratings to these hygiene factors in both studies. Principals with more experience have a higher satisfaction with their sense of accomplishment than principals with less experience. These findings are the same in both studies. The studies found that the principals were satisfied in their current position and they perceived satisfaction in their career in the principalship.

Another interesting finding is how females and males perceive some factors. While statistically significant differences are seen between females in both studies on one motivator factor, (the process the superintendent uses to evaluate principals), six significant differences are seen between male principals in both studies. These include two motivators (how well the board of education acknowledges principal's accomplishment and the community's image of school administrators); three hygiene factors (consistency of the board in making decisions in the best interest of students, relationship with the board of education, and annual salary); and in overall job satisfaction. In all of these factors, principals were more satisfied in the 2005 study than in the 1999 study. Male principals in the 1999 and the 2005 studies were more satisfied with their annual salary than female principals. These findings are consistent with Graham and Messner's (1998) study. In addition, Gates, Ringel, Santibanez, Chung, and Ross (2003) found that women received comparable pay for the same work in the public sector.

\section{Less Experienced Principals have more Problems in Leading their Schools}

When looking at years of experience in the principalship, results show principals with more experience have a higher satisfaction level with the sense of accomplishment. This trend appears in both studies. Less experienced principals have more problems in leading their schools at the beginning of their career than older and more experienced principals. In both studies, more experienced principals are also very satisfied with the relationship with the parents. The number of years principals serve in their present schools indicates that principals serving 1-5 years are less satisfied in the 2005 study with the adequacy of administrative support provided for principals than in the 1999 study. Do newly appointed principals need more time to show their ability? Do they need more time to build relationships with colleagues, teachers, or the board of education?

When looking at the category of principals who served 610 years in their present schools, differences appear in the areas of school policy and administration, recognition, salary, and work itself. The relationship with the teachers is significant for principals serving 11 years or more in their present schools. On the other hand, the mean scores for all of these factors are significantly higher in the 2005 study than in the 1999 study. Why are principals more satisfied? Is it because districts now have better school policy? Do principals have better relationships with superintendents? Is the process a superintendent uses to evaluate principals better? Do the principals now have higher salaries than six years ago?

The results when looking at types of schools show that most differences are found at middle/junior high school level in the areas of community demands, time available that puts balance in the life of principals, relationship with the board of education, consistency of the board in making decisions in the best interest of students, how well the board of education acknowledges principals' accomplishments, salary, community's image of school administrators, the process the superintendent uses to evaluate principals, and overall job satisfaction. The satisfaction with these motivator and hygiene factors is higher in the 2005 study. However, no differences are seen for high school principals. 
Moderate positive correlations were found between time spent on management tasks and overall job satisfaction and time on leadership activities and overall job satisfaction in both studies. These results show a stronger degree of relations between these two factors in the 2005 study. Differences in the 1999 study and 2005 study are found in three motivator factors and three hygiene factors. Principals are more satisfied in the 2005 study than in 1999 study with recognition, personal life, school policy and administration, and salary.

\section{Satisfaction with Hygiene Factors}

The results of this research show that Iowa public school principals are more satisfied with the hygiene factors than with the motivators in both studies. Thus, this study does not support Herzberg's Two-Factor Theory. The results of the 1999 and 2005 studies also contradict Ford, Borghata and Bohrnstedt (1968) who claimed that only individuals who prefer motivators should be considered as candidates for administrative positions. All other candidates who prefer hygiene factors should be regarded as undesirable candidates for administrative positions.

\section{Implications}

To motivate principals into higher performance, motivation factors are needed. Schools need a clear understanding of what principals personally find satisfying or dissatisfying about their jobs. This is a task for school communities, boards of education, and superintendents. Principals as middle level managers compare their possibilities and opportunities for promotion and professional growth with other categories of managers. More autonomy in personal management, redesign expectations, reevaluation of their workload, and compensation will lead to higher job satisfaction and higher motivation for principals. It is necessary to reduce time demands, improve salaries, and increase administrative support and support services. University preparation programs, pre-service, and in-service training have to make greater effort to better prepare potential candidates for the principalship. New principals have to be prepared to face all aspects of their new jobs. They have to be prepared for longer working time, time pressures, how to deal with stress, budget cuts, security issues and other tasks that draw large amounts of the principals' time. Principals need good skills in leadership, management, communication and the decision making process. Thus, if we want to attract new people into school administration, we must ensure that the job meets needs of those who are interested in entering the principalship.

To retain principals, we must enable them to develop and utilize their expertise and ability. If job satisfaction is to remain high, we need to address problems principals face and look for ways to help them to work effectively and productively. Despite budget cuts and school financial problems, it would be useful for boards of education and superintendents to hire assistant principals or School Administration Management Systems (SAMS) for schools with higher student populations.

\section{We Need More Women for the Principalship}

More women are needed for the principalship, mainly at the high school level. In the 2004-2005 school year, 35.5\% of principals in Iowa were females. The differences in sex are not related to the function of school management or leadership. Because of more culturally diverse student populations, which are growing rapidly, it is also necessary to hire minority principals. The current ethnical diverse number of principals is small in Iowa.

The findings of this research provide insight into the job satisfaction of Iowa public school principals in 1999 and 2005. The results should be beneficial to state legislators, district administrators, boards of education, and superintendents in redefining job responsibilities and for a better understanding of the complexity of the job. The subjects of the study were public principals of elementary, middle, and high schools in Iowa. Therefore, the results cannot be generalizable to states other than Iowa. The results did not measure perceptions of job satisfaction in parochial and private schools.

\section{References}

Behrens, G. M. (2003). Factors associated with the decision not to become 7-12 principals by those holding the

license. Unpublished doctoral dissertation. University of Northern Iowa.

Blackman, M. C., \& Fenwick, L. T. (2000). The principalship: Looking for leaders in a time of change. Education Week, 3(19), 68-70.

Educational Research Service. (2000). The principal, keystone of a high achieving school: Attracting and keeping the leaders we need. Arlington, VA: National Association of Elementary School Principals and National Association of Secondary School principals.

Else, D., \& Sodoma, B. (1999). Principal shortage and job satisfaction survey. Cedar Falls: University of Northern Iowa, Institute for Educational Leadership.

Ford, R. N., Borghata, F. F., \& Bohrnstedt, G. W. (1968). The work components study: A revised set of measures for work motivation. Multivariate Behavior Research, 3, 403-414.

Gates, S., Ringel, J., Santibanez, L, Chung, C., \& Ross, K. (2003). Who is leading our schools? Santa Monica, CA: RAND.

Graham, M. W., \& Messner P. E. (1998). Principals and job satisfaction. International Journal of Educational Management 12(5),196. 
Herzberg, F., Mausner, B. \& Snyderman, B.B. (1959). The motivation to Work. ( $2^{\text {nd }}$ nd.). New York, Willey.

Institute for Educational Leadership. (2000). Leadership for student learning: Reinventing the principalship. A report of the task force on the principalship. Washington, D.C.

Mack, P. A. (2000). Perspectives on principals on job satisfaction. Unpublished doctoral dissertation, Georgia State University, Atlanta.

National Association of Elementary School Principals. (2003). NAESP fact sheet on the principalship shortage. Retrieved December 2, 2006 from

http//:www.naesp.org/contentLoad.do?contendl=1097

No Child Left Behind (NCLB) Act of 2001, Pub. L. No. 107-110, 115 Stat. 1425 (2002, January 8).

Rayifield, R., \& Diamantes, T. (2003). Principal satisfaction and the shortage of educational leaders. Retrieved February 27, 2004, from http://www.principals.org/publications/connections/ rayfield.cfm
Sablatura, D. A. (2002). Comparisons of job satisfaction among urban, suburban, and rural school principals. (Doctoral dissertation, University of Houston, Texas, 2002). Dissertation Abstract International 63 (02) 455A. (UMI No AAT 3042448).

Salant, P., \& Dillman, D.A. (1994). How to conduct your own survey. New York: John Wiley \& Sons.

Schmidt, J. J., Weaver, F. S., \& Aldredge, A. L. (2001). Perceptions of school counselor's role and satisfaction by newly hired counselors and principals in Eastern North Carolina. Available at http://www.eric.ed.govcontentdelivery/servlet/ ERICServlet?accno=ED457470 